\title{
İSLAM CEZA HUKUKU BAĞLAMINDA BÜYÜCÜLÜK SUÇU
}

Crime of Witchcraft in the Context of Islamic Criminal Law

\section{Yusuf Erdem GEZGIN}

Arş. Gör. Dr., Karamanoğlu Mehmetbey Üniversitesi İslami İlimler Fakültesi Temel İslam Bilimleri Bölümü İslam Hukuku Anabilim Dalı, Karaman, Türkiye Res. Assist. Dr., Karamanoglu Mehmetbey University Faculty of Islamic Education Department of Basic Islamic Sciences Department of Islamic Law, Karaman, Turkey yegezgin@kmu.edu.tr | https://orcid.org/0000-0002-0221-8965

(i) Makale Bilgisi / Article Information: Makale Türü / Article Type: Araştırma Makalesi / Research Article Geliş Tarihi / Received: 24.04.2020 Kabul Tarihi / Accepted: 05.09.2020 Yayın Tarihi / Published: 31.12.2020

99 Atıf / Cite as: Gezgin, Yusuf Erdem. "İslam Ceza Hukuku Bağlamında Büyücülük Suçu”. Mütefekkir 7/14 (2020), 467-483. https://doi.org/10.30523/mutefekkir.848019

(C) Telif / Copyright: Published by Aksaray Üniversitesi İslami İlimler Fakültesi / Aksaray University Faculty of Islamic Education, 68100, Aksaray, Turkey. Tüm Hakları saklıdır / All rights reserved.

İntihal / Plagiarism: Bu çalışma hakem değerlendirmesinden geçmiş, bir intihal yazılımı ile taranmıștır. İntihal yapılmadığı tespit edilmiștir. This article has gone through a peer review process and scanned via a plagiarism software. No plagiarism has been detected. 


\title{
İSLAM CEZA HUKUKU BAĞLAMINDA BÜYÜCÜLÜK SUÇU
}

Öz

İslam ceza hukuku bağlamında büyücülük konusunun ele alındığı bu çalışmada ilgili suçun uhrevi boyutundan ziyade dünyevi ceza boyutu değerlendirilmiştir. Pozitif ceza hukukunda büyücülüğün cezası sadece halkın dini duygularını istismar ve nitelikli dolandırıcılık gibi unsurlar üzerinden değerlendirilmektedir. Halbuki İslam ceza hukukunda konunun bağlamı direk fâilin gerçekleștirdiği büyü fiilidir. Bu kapsamda ilk olarak büyücülük ve büyü ile ilgili kavramsal bir çerçeve sunulmuş; çalışmanın temel problemi ele alınmıștır. Akabinde gerek fikıh mezhepleri gerek ilgili mezheplerin mensup oldukları kelâm otoritelerine göre büyünün hakikat veya hayal olmasıyla ilgili mahiyet tartışmaları değerlendirilmiştir. Ayrıca büyücülüğün fıkhî hükümleri kapsamında mezheplerin görüşleri ayrıntılı olarak ele alınmıştır. Tabiatıyla ceza hukuku bağlamında bir hüküm verebilmek için kavram analizi, problemin mahiyeti ve fikhî hükümlerin ele alınması zaruridir. Büyücülüğün mahiyeti ve fıkhî hükmü konusunda bir neticeye ulaştıktan sonra ceza hukuku bağlamında görüşler ifade edilmiştir. Neticede ulaşılan sonuç ve değerlendirmeler ile çalışma araştırmacılara sunulmuştur.

Anahtar Kelimeler: İslam Ceza Hukuku, Sihir, Büyü, Had, Ta'zir.

\section{Crime of Witchcraft in the Context of Islamic Criminal Law}

\begin{abstract}
In this study, which the subject of sorcery/witchcraft in the context of Islamic criminal law is evaluated in, the worldly punishment dimension of the relevant crime was looked into rather than the afterlife dimension of the crime. In secular criminal law, the punishment of witchcraft is assessed only on factors such as exploiting the religious feelings of the people and qualified fraud. However, in Islamic criminal law, the context of the subject is the act of witchcraft performed directly by the perpetrator. In this context, we first presented a conceptual framework about witchcraft. Then we evaluated the arguments of both fiqh sects and theology sects about whether magic is real or imaginary. In addition, within the scope of the fiqh provisions of sorcery, the views of the sects have been discussed in detail. Naturally, in order to make a judgment in the context of criminal law, it is essential to analyze the concept, the nature of the problem and the judicial provisions. After reaching a conclusion about the nature and fiqh judgment of witchcraft, opinions were expressed in the context of criminal law. Eventually, the study was presented to the researchers with the results and evaluations reached.
\end{abstract}

Keywords: Islamic Criminal Law, Magic, Witchcraft, Hadd, Ta'zir.

\section{GİRİ̧}

Güç ve gizem, insan doğasının ilgi duyduğu iki önemli husustur. İnsan doğasında bir şeylere sahip olma/elde etme arzusu da bulunmaktadır. Esasında bu arzunun temelinde güçlü ve üstün olma isteği vardır. Güç sahibi olma arzusunun metafizik boyutu ise gizemdir. Metafizik bir olgunun fiziki ortama yansıması olarak bilinen büyü olgusunda, güç ve gizem unsurları birleşmektedir. İşte makalemiz böyle bir olgu üzerinden davranışlar sergileyen bireylerin hukuki sorumluluklarını ele alacaktır.

Ayrıca güçlü olma isteğinin altında merak duygusunun varlığı da söz konusudur. Bireyler merak ettiği şeyin mahiyetine ulaşmak için somut argü- 
manlara başvurduğu gibi soyut argümanlara da başvurmaktadırlar. Geçmişten günümüze kadar bu duygular büyü vb. şeylerle tatmin edilmeye çalışllmıştır. Bu anlamda büyü konusu çok çeşitli araştırmalara konu olmuştur. Fizik, psikoloji, sosyoloji, felsefe ve teoloji büyüyle ilgili araștırma yapılan alanların bir kısmıdır. Teolojik açıdan büyüyle ilgili yapılan çalışmalara İslami ilimler de kayıtsız kalmamıștır. Büyü konusu İslami ilimlerin; kelâm/akâid, hadis ve tefsir alanlarının gündemine metafizik boyutuyla girmiştir. Flkıh ilmi ise büyünün mahiyetinden/metafizik boyutundan ziyade sonuçlarıyla ilgilenmiştir. Bu anlamda fikıh/fakîh büyünün tesirinden öte; büyü ile meşgul olmanın hükmü, büyü yapılan kişinin hak ve sorumlulukları açısından ehliyeti, büyücülük yapan kişinin yaptığı bu ameliye nedeniyle sebep olduğu sonuçlar konusundaki sorumluluğu gibi konuları incelemiştir. Tabiatıyla bu ve benzeri konular hakkında bir hüküm tesis edebilmek için büyü ve büyücülügün mahiyetini bilmek büyük öneme sahiptir. Bu nedenle fikıh mezhepleri kelâm otoritelerinin görüşlerinden de istifade ederek hükme varmışlardır.

Bu çalışmada, önce büyü ile ilgili kavramsal bir çerçeve çizilecek, konuyla ilgili kelime ve kavram haritası sunulacaktır. Konunun kavramsal analizinden sonra büyünün hakikati/gerçekliği ve çeşitleriyle ilgili temel bilgiler verilecek, sonra fakîhlerin büyü konusundaki kanaatleri açılanacaktır. Son olarak araştırma konumuz olan büyücülük suçunun cezasıyla ilgili klasik fikıh literatüründeki görüşlere yer verilecektir.

\section{KAVRAMSAL ÇERÇEVE VE PROBLEM ALANI}

Çalışmada günümüz dilindeki kullanım sıklığına binaen büyü ve büyücü kelimeleri tercih edilmiş olsa da klasik fikıh literatüründe bizim bugün büyü olarak ifade ettiğimiz ameliye için sihir ve bu işle uğraşan kimselere sâhir kavramları kullanılmaktadır. ${ }^{1}$ Günümüzde ise sihir ve sihirbaz kavramları yerine, illüzyon ve illüzyonist kavramları kullanılmaktadır. Bu çalışmada büyü, illüzyon manasında kullanılmayacaktır. Bu çerçevede konumuzla alakalı kavramlar; sihir, büyü, tencîm, 'ırâfe, tılsım, vefk, rukye, neşra, azîme ve şa'veze/şa'bezedir. Bu kavramlardan sihir dışındakiler kısaca açıklandıktan sonra konumuzu tam olarak ifade etmesi nedeniyle sihir kavramına açıklık getirilecektir.

Вüyӥ: "Tabiat üstü gizli güçlerle ilişki kurularak yahut kendilerinde gizli güçler bulunduğuna inanılan bazı tabiî nesneler kullanılarak zararlı, faydalı veya koruma gayeli bazı sonuçlar elde etmek için yapılan işler"2 şeklinde tarif edilmektedir. Büyü bu manasıyla sihirle aynı manada olduğu görülmektedir.

Tencîm: Sözlükte yıldızlara bakmak olarak ifade edilirken, ıstılahta gök

1 Daha geniş bilgi için bk. Aydın Kaya, Kur'an'da Mâhiyet Açısından Sihir-Mucize Karşılaştırması (Sivas: Cumhuriyet Üniversitesi, Sosyal Bilimler Enstitüsü, Yüksek Lisans Tezi, 2015), 30-31.

2 Hikmet Tanyu, “Büyü”, Türkiye Diyanet Vakfı Íslâm Ansiklopedisi (Erişim 17 Nisan 2020). 
cisimlerine bakmak sûretiyle yeryüzünde olacak olaylar hakkında haber vermektir. Günümüzde bu kavram çoğunlukla astroloji falcılığı olarak bilinmektedir. ${ }^{3}$

'Irâfe: Arrâf adı verilen kişilerin geçmişten haber verme işlemlerine 'ırâfe denir. Arrâf ile akla ilk etapta kahinler gelir. Fakat arrâfın kâhinden farkl; kâhin geçmiş ve gelecekten haber verirken arrâf sadece geçmişte olan olaylardan haber verir. ${ }^{4} \mathrm{Bu}$ eylem büyü ve sihirden oldukça farklıdır. Arrâflara müracaat edenlerin amacı başlarına gelen olayların arka planıyla ilgili bilgi almaktır. Arrâflar da bu bilgileri cinlerden öğrenip insanlara aktarırlar. ${ }^{5}$ Fakat Hz. Peygamber (s.a.) arrâfa itibar ederek bunları tasdik etmeyi yasaklamış, onlara itibar etmeyi Kendisini (s.a.) inkâr ile eş tutmuş, namazlarının kırk gün kabul edilmeyeceğini ve cennete giremeyeceklerini bildirmiştir. ${ }^{6}$

Tılsım: Bir şeyler elde etmek veya korkulan bir şeyden korunmak için yıldızlarla alakalı olduğu düşünülen isimlerin ve şekillerin bir takım mâdenî eşyalara yazılmasıdır. ${ }^{7}$

Vefk: "Harf, rakam, kelime, esmâ-i hüsnâ, âyet ve sûrelerin belli bir düzene göre kareler içine yazılarak bunda bâtınî mânalar arayan bir tılsım türü"8 olarak bilinmektedir.

Rukye: Hastalıklar için okunan veya yazılan ve kendisi aracılığıyla şifa umulan lafızlardır. ${ }^{9}$ Naslarda meşru rukye çeşitleri ifade edildiği gibi meşru olmayan rukyeler de açıkça beyan edilmiştir. ${ }^{10}$

Neşra: Meşru olmayan bir tür rukye olan neşra, kendisine cin musallat olduğu düşünülen kimseyi bu durumdan kurtardığı düşünülen bir çeşit uygulamadır. ${ }^{11} \mathrm{~Hz}$. Peygamber'e (s.a.) bu ameliyye sorulduğunda; "O (s.a.) bu işin şeytanın ameliyelerinden olduğunu"12 beyan etmiştir.

3 Sa'dî Ebû Habîb, Kâmûsu'l-fikhî luğaten ve ıstılâhen (Dımaşk: Darü'l-Fikr, 1988), 348; Muhammed Revvâs Kal'acî - Hâmid Sâdık Kuneybî, Mu'cemu luğati'l-fukahâ (Beyrut: Dâru'n-Nefâis, 1985), 147.

4 Ebû Yahya Zeynüddîn Zekeriya b. Muhammed b. Ahmed es-Süneykî Zekeriyyâ el-Ensârî, Esne'lmetâlib fi șerhi Ravzi't-tâlib (Beyrut: Daru'l-Kütübi'l-İlmiyye, 2000), 4/82.

5 Ebü'l-Fazl Şihâbüddîn Ahmed b. Alî b. Muhammed İbn Hacer, Fethü'l-bârî şerhu sahîhi'l-Buhârî (Beyrut, 1960), 10/216.

6 Ahmed b. Hanbel, Müsned, thk. Şuayb el-Arnaût, Âdil Mürşid vd. (Müessesetü'r-Risâle, 1421), 15/331; 27/198; b. Haccac Ebu'l-Hüseyn el-Kuşeyrî Müslim, el-Câmiu's-Sahîh (Beyrut: Dâru ihyâi't-türâsi'l-arâbî, ts.), "Selâm", 125; Süleyman b. Eş'as b. İshak el-Ezdi Ebû Dâvûd, Sünenü Ebî Dâvûd, thk. Şuayb el-Arnaût, Muhammed Kâmil (Dârü'r-Risâleti'l-Âlemiyye, 2009), "Tib", 21; Ebû İsa Muhammed b. İsa b. Sevre Sülemi Tirmizî, el-Câmiu'l-kebîr, thk. Beşşâr Avvâd Marûf (Beyrut: Dârü'l-Garbi'l-İ́slâmî, 1998), "Tahâret", 102.

7 Kal'acî - Kuneybî, Mu'cemu luğati'l-fukahâ, 292.

8 İlyas Çelebi, “Vefk”, Türkiye Diyanet Vakfi İslam Ansiklopedisi (Erişim 19 Nisan 2020).

9 Sa'dî Ebû Habîb, Kâmûsu'l-fikhî luğaten ve istılâhen, 152.

10 Meşru olan ve olmayan rukyeler için bk. "Rukye”, Mv. F. (Kuveyt, ts.), 23/96-98.

11 Ebü'l-Feyz Muhammed el-Murtazâ b. Muhammed b. Muhammed b. Abdirrezzâk el-Bilgrâmî elHüseynî Zebîdî, Tâcu'l-'arûs min cevâhiri'l-kâmûs (Riyad: Daru'l-Hidâye, ts.), 14/217.

12 Ebû Muhammed Bedreddin Mahmûd b. Ahmed b. Musa Hanefi Aynî, Umdetü'l-kârî șerhu sahîhi'l- 
Azîme: Rukye kapsamında birtakım işlerle kişinin cinlerden yardım alması olarak bilinir. Hz. Süleyman'ın (a.s.) cin taifelerine, meleklere ait olduğu düşünülen isimler koyduğu ve bazı kişilerin bu isimleri kullanarak cinlerden yardım aldıkları iddia edilmektedir. İşte bu işe azîme (ç. azâim) denilmektedir. ${ }^{13}$

Şa'veze/Şa'beze: Bir şeyi olduğu şekilden farklı göstermek için el çabukluğu yapmak ve illüzyondur. ${ }^{14}$ Günümüzde sihir denilince şa'veze akla gelmektedir. ${ }^{15}$

Büyü ile ilgili olduğunu düşündügümüz bu kavramlardan sonra çalışmamızın asıl problematiği kapsamında sihir kavramını açıklayacağız. Sihir sözlükte "el çabukluğu, göz boyama ve yaldızlı sözler söyleme yoluyla gerçekleştirilen hile ve aldatma işi, şeytanla yakınlı kurup ondan yardım alma ve nesnelerin şeklini değisstirme iddiası"16 şeklinde tanımlanmıştır.

Sihrin ıstılahî manasını ifade etmeden önce şu hususu tekrar etmemiz gerekir: Sihir kavramı klasik fıkıh eserlerinde "büyü" anlamını ifade etmek üzere kullanılmışken, günümüzde illüzyon anlamını karşılamak üzere kullanıldığı görülmektedir. Başka bir ifade ile, günümüzde "büyü" kavramı ile ifade edilen olgunun İslam ceza hukuku bağlamında "sihir" başlığı altında ele alındığını söyleyebiliriz. Ayrıca gizemli ve metafizik bir olgu olmasıyla birlikte neden olduğu olumsuz sonuçlar itibariyle net bir şey ifade edilememesi, üzerinde ittifak edilmiş bir sihir tanımının yapılamamasına neden olmuştur. $\mathrm{Bu}$ anlamda sihrin hayalden öte hakikat olduğu düşüncesini benimseyen şu tarif ile sihri açıklayacağız:

Sihir: "Kötü niyetli kişinin (sâhir) şeytanlardan yardım almak sûretiyle; kişinin (meshûr) bedeninde, kalbinde, aklında birtakım tesirler oluşturması veya şeytanları sihir yapılan kişiye musallat etmesi" şeklinde tanımlanmaktadır. ${ }^{17} \mathrm{Bu}$ tanım Hanbelîlere ait olup ${ }^{18}$ maksadımızı net olarak açıklaması nedeniyle tercih edilmiștir.

Bir diğer tanım ise șöyledir: Olağanüstü/harikulade veya ona yakın bir

Buhârî (Beyrut: Dâru İhyâi't-Türâsi'l-Arabî, ts.), 22/135.

13 Muhammed b. Mükerrem İbn Manzûr, Lisânu'l-'Arab (Beyrut: Daru Sadr, 1993), 12/400; Ebü'lAbbâs Şihâbüddîn Ahmed b. İdrîs b. Abdirrahmân el-Mısrî Karâfî, Envârü'l-burûk fí envấ' 'i'l-fürûk (Beyrut, 2014), 4/147; Ayrıca bk. Süleyman Uludağ, "Azâim", Türkiye Diyanet Vakfı İslam Ansiklopedisi (Erişim 19 Nisan 2020).

14 Kal'acî - Kuneybî, Mu'cemu luğati'l-fukahâ, 431.

15 İllüzyon, sözlükte göz bağı ve yanılsama anlamına gelmekte olup duyumların zihinde yanlıș yorumlanması bu kavramla ifade edilmektedir. Bk. Güncel Türkçe Sözlük, ts., "illlüzyon”; “illüzyon Nedir? Neden Algı Yanılması Yaşarız" (Erişim 19 Nisan 2020).

16 İlyas Çelebi, "Sihir", Türkiye Diyanet Vakfi İslâm Ansiklopedisi (Erişim 17 Nisan 2020).

17 Ahmed Fethî Muhammed Abdüllatif Bukeyrî, Ahkâmu'l-müte'allika bi's-sihr ve's-sehara fi'l-fikhi'lİslâmî (Kuala Lumpur: Câmiatu'l-Medîne el-Âlemiyye, 2016), 12.

18 Ebû Muhammed Muvaffakuddîn Abdullah b. Ahmed b. Muhammed b. Kudâme Cemmâîlî Makdisî İbn Kudâme, el-Muğnî (Mektebetü'l-Kâhire, 1968), 9/28; Mansur b. Yûnus Buhûtî, Kesş̧âfü'l-kınâ' an metni'l-İknâ' (Riyad: Daru'l-Kütübi'l-İlmiyye, 2003), 6/186. 
durumu ortaya çıkarmak için çok gizli bir kısım işlerden ibarettir. Bu işlerin göz boyamak ve aldatmak konusunda herhangi bir sınırı yoktur. Ayrıca bu kötü fiili gerçekleştiren kişinin (sâhir), etki etmek istediği kişiyle/şeyle aynı ortamda olup olmamasının da etki konusunda herhangi bir sınırı söz konusu değildir. ${ }^{19}$

Kavramsal çerçeve ile ilgili ifade edilen bu hususlarla kifâyet ettikten sonra araștırmanın problem alanı ifade edilecektir. Bilindiği üzere pozitif ceza hukuku manevi haklar ve ihlaller (kişilik ve onur hakları) dışında mağdurun yaşadığı ruhsal bozukluklar vb. metafizik suç ve unsurlarıyla ilgilenmemiştir. Bu noktada büyü ve büyücülük konusu halkın dini duygularının istismarı, bu duygular üzerinden haksız kazanç elde etme ve nitelikli dolandırıcılık unsurları üzerinden değerlendirilmiştir. ${ }^{20} \mathrm{Bu}$ kapsamda pozitif ceza hukukunda suçlu için öngörülen ceza üç ylldan on ylla kadar hapis ve beş bin güne kadar adlî para cezasıdır. ${ }^{21}$

İslam ceza hukuku bağlamında bu suçun ispat edilme güçlüğü ile beraber, suç unsurlarının saptanması için gerekli olan veriler sübjektiftir. Fakat büyünün varlı̆̆ı hakkındaki naslardaki sarih ifadeler, büyünün bozulmasına dönük terkip önerileri ve büyü yoluyla insanlara zarar veren suçlunun cezasıyla ilgili hükümler nedeniyle İslam ceza hukuku bu probleme kayıtsız kalmamıştır. Bu çerçevede araştırma konumuzun problem alanı olarak gördüğü konu, büyü gibi metafizik bir suçun ispat vasıtaları ve bu suçu işleyen kişiye uygulanması gereken yaptırımlardır.

Tabiatıyla büyünün yapılma usulleri çalışmamız kapsamında değerlendirilmeyecektir. Zira bu konunun çalışmanın kapsam dışında olduğu takdir edilmelidir. Şu kadarını ifade edelim ki; evli veya nişanlı çiftlerin arasını bozma (tefrik), bu kapsamda cinselliği olumsuz etkileme (bağlama/'akd), yahut aralarında sevgi olmayan bireyleri evlenme veya birlikte olmak kastıyla birbirine yakınlaştırma (tahbîb), kıskançlık nedeniyle bireylere zarar verme gibi birçok sebeple büyüye başvurulmakta ve farklı terkipler uygulanmaktadır. Bu bağlamda büyücü; mağdura ait kişisel eşyalara (saç, tüy, ip vb.) düğümler atıp okur, farklı metotlarla hazırladığı gıdaları mağdura yedirir/içirir, yoluna döker veya meşru olmayan birtakım kelime ve cümleleri nüshalara (halk diliyle muska) yazıp, bu nüshayı mağdurun evine, işyerine bırakarak büyü yaptığını ifade eder. ${ }^{22}$

\section{BÜYÜNÜN GERÇEKLİĞİ/HAKIKKATI}

Büyünün mahiyeti hakkında iki farklı görüşün benimsendiği görülmektedir. Bu bağlamda bir kısım İslam âlimleri büyünün sözlük manasına atıfla

19 Huseyn Cüley'ab Sa'îdî, es-Sihr hakîkatuhû ve hukmuhû, ts., 342.

20 Türk Ceza Kanunu (Türk Ceza Kanunu), Nitelikli Dolandırıcılık 5237-158/1-a) bendi (26 Eylül 2004).

21 Türk Ceza Kanunu, 158/1-L.

22 Bukeyrî, Ahkâmu'l-müte'allika bi's-sihr, 46-52. 
hakikatinin olmadığını ve hayal mahsulü olduğunu iddia ederken bazısı da büyünün hakikat olduğuna vurgu yapmışlardır. Bu çerçevede Ehl-i sünnet âlimlerinin çoğunluğuna göre, büyünün hakikati vardır ve meydana getirdiği netice somut olarak görülmektedir. Büyünün hakikatinin varlığını kabul eden Ehl-i sünnet mezhebinin çoğunluğu içerisinde Eş'arî kelâm geleneğine mensup olan Mâlikî, Şâfiî ve Hanbelîler ve İbnü'l-Hümâm gibi bazı Mâtürîdî/Hanefîler bulunmaktadır. ${ }^{23}$ Hanefîlerin itikâdî görüşlerini sistematize eden Mâtürîdî kelâm geleneğine, Mu'tezile'ye ve Zâhirîlere göre ise büyünün hakikati yoktur, hayal ve temsil neticesinde ortaya çıkmaktadır. ${ }^{24}$

Büyünün hakikatinin olmadığını ifade edenler arasında Şâfiîlerden Begavî (ö. 516/1122) olduğu ifade ediliyor ${ }^{25}$ olsa da bu iddia ilgili fakîhin eserlerindeki ifadelerle çelişmektedir. ${ }^{26}$ Zira onun sihrin hakikatinin olmadığını ifade ettiği düşünülen ifadeleri, Hz. Musa (a.s.) ile sihirbazlar arasında gerçekleşen olayda, sihirbazlara ait olan fiillerle ilgilidir. ${ }^{27}$

Her iki görüşü savunan fakîhlerin de delilleri bulunmaktadır. ${ }^{28}$ Çalışmamızın hacmi nedeniyle ilgili delillere ve tartışmalara değinilmeyecektir. Ayrıca her iki görüş sahibi fakîhler büyücülük yapan kimsenin cezalandırılması gerektiği konusunda ittifak etmişlerdir. Biz de büyünün hakikatinin olduğu ve tesirinin mevcudiyeti konusunda cumhurun görüşünün daha isabetli olduğu kanaatindeyiz. Zira hakikati olmayan bir unsura dayalı olarak bireylerin cezalandırılması mümkün değildir. Bu kapsamda aşağıda ifade edilecek olan büyü ve büyücülüğün fikhî hükmü, fakîhlerin ceza hukuku bağlamında büyücülükle ilgili görüşlerini de şekillendirecektir.

23 Kemalüddin Muhammed b. Abdulvâhid İbnu'l-Hümâm, Şerhu Fethu'l-Kadîr (Beyrut: Darü'l-Fikr 2003), 6/98-99; Karâfî, Envârü'l-burûk, 4/149-150; Zekeriyyâ el-Ensârî, Esne'l-metâlib fí şerhi Ravzi't-tâlib, 4/82; Süleyman b. Ömer b. Mansûr el-Ezherî Cemel, Fethu'l-Vehhâb bi tavzîh-i şerhi menheci't-tullâb (Kahire: Darü'l-Fikr, 1994), 5-110; İbn Kudâme, el-Muğnî, 9/28.

24 Ebû Mansûr Muhammed b. Muhammed b. Mahmûd el-Mâtürîdî es-Semerkandî Mâtürîdî, Kitâbu'tTevhîd (Mısır, ts.), 1/201; Ebû Bekr Ahmed b. Alî Râzî Cessâs, Ahkâmü'l-Kur'ân (Beyrut, 1994), 1/49-70; Ebû Saîd Nasîruddîn Abdullah b. Ömer b. Muhammed Beyzâvî, Envâru't-tenzîl ve esrâru't-te'vîl (Beyrut, 1998), 1/97; Muhammed b. A'la b. Ali el-Fârukî el-Hanefî Tehânevî, Keşşâf ıstılâhâti'l-funûn (Beyrut: Mektebetu Lübnân, 1996), 1/935-941; Ebü'l-Hasen Kâdı'l-kudât Abdülcebbâr b. Ahmed b. Abdilcebbâr el-Hemedânî Kâdî Abdülcebbâr, Tenzîhü'l-Kur'ân 'ani'lmetâ'in (Kahire, ts.), 28; Ebû Muhammed b. Ali b. Ahmed b. Saîd ez-Zahiri İbn Hazm, Muhallâ bi'lâsâr (Beyrut: Darü'l-Fikr, 1934), 1/58.

25 Bk. Bukeyrî, Ahkâmu'l-müte'allika bi's-sihr, 20; "Sihr”, Mv. F. (Kuveyt, ts.), 24/262.

26 Ebû Muhammed Muhyissünne el-Hüseyn b. Mes'ûd b. Muhammed el-Ferrâ'Begavî, Şerhu's-sünne (Beyrut: Mektebetü'l-Îslâmî, 1983), 12/184-189.

27 Ebû Muhammed Muhyissünne el-Hüseyn b. Mes'ûd b. Muhammed el-Ferrâ' Begavî, Me'âlimü'ttenzîl (Riyad: Dâru's-Selâm, 1997), 3/265. Metin şu şekildedir:

\} قال\{ موسى بل \}ألقوأ أنتم، \}فلما ألقوا سحروا أعين الناس\{ أي: صرفوا أعينهم عن إدراك حقيقة ما فعلوه من التمويه والتخييل، وهذا هو السحر.

28 Konuyla tarafların delilleri ve karşı argümanlarının ayrıntıları için bk. Ebû Zekeriyya Yahya b. Şerif b. Mürî Nevevî, el-Mecmû' șerhu'l-Mühezzeb (Fethu'l-'azîz ve Telhîsu'l-habîr ile Sübkî'nin ve Mutî̀înnin tekmileleri ile birlikte) (Beyrut: Darü'l-Fikr, ts.), 19/240-246; Tehânevî, Keşşâf ıstılâhâti'l-funûn, 1/935-940; Bukeyrî, Ahkâmu'l-müte'allika bi's-sihr, 17-20. 


\section{BÜYÜ İLE ÍLGILII FIKHÎ GÖRÜŞLER}

Büyü konusu fıkhî açıdan üç farklı perspektiften ele alınacaktır. Bunlar; (a) büyünün genel hükmü, (b) büyü yapmayı öğrenmek ve öğretmek, (c) ceza hukuku bağlamında büyücülük konularıdır. Bu başlıkta ilk iki konu değerlendirilecek, büyücülügün cezalandırılmasıyla ilgili hükümler ise bir sonraki başlığa havale edilecektir. Büyü konusunda diğer bir fikhî başlık ise büyüye maruz kalmış bireyin (meshûr) bu durumundan meşru bir şekilde kurtulmasının hükmüdür. Takdir edilmelidir ki konunun bu yönü çalışmamızın hacmi açısından elverişli değildir. Büyüden kurtulmayla ilgili müstakil çalışmalar yapılmış, konu ilgili eserlerde ayrıntılı olarak açıklanmıştır. ${ }^{29}$

a) Büyü, Kitap ${ }^{30}$ ve Sünnet ${ }^{31}$ delilleri çerçevesinde haramdır ve büyük günahlardandır. Hatta büyünün haramlı̆̆ konusunda Nevevî ve İbn Teymiyye icma iddiasında bulunmuşlardır. ${ }^{32}$ Fakat illüzyon gibi el çabukluğu ve göz boyama yoluyla yapılan işlerin câiz olduğu beyan edilmektedir. Tabiatıyla herhangi bir harama vesile olmaması ön şarttır. ${ }^{33}$

b) Büyü yapmayı öğrenmek ve öğretmek hususunda ise iki görüș bulunmaktadır. Her iki görüşe göre de büyü yapmak haramdır fakat büyü yapmaya tevessül etmeksizin sadece bilgi sadedinde bu işin öğrenime konu edilmesi konusunda görüş ayrılığı vardır. Bu kapsamda görüş ayrılığının temel noktası büyü yapmanın itikâdî boyutta küfür olup olmamasıyla ilgilidir.

1. Şâfîllere ve Hanefî fakîh İ̉nü'l-Hümâm'a göre büyü yapmak haram olduğu halde bu işin bizzat kendisi küfrü gerektirecek bir fiil değildir. Şayet büyücü yaptığı büyünün mübah bir davranış olduğunu düşünüyorsa veya küfür olduğuna inanarak yapıyorsa ve şeytanların kendi istediği her şeyi yapabileceklerine inanıyorsa bu takdirde yapılan işin küfür olduğunda herhangi bir tereddüt söz konusu değildir. ${ }^{34}$ Zâhirîlerin görüşleri de Şâfîllerin görüşlerine yakındır. ${ }^{35}$

2. Hanefî, Hanbelî ve Zeydîler ise büyücü yapmış olduğu işin küfür oldu-

29 Bk. Veli Atmaca, Hadislerde Rukye Hz. Peygamber ve Sahabenin Uygulamaları Işı̆̆ı̆nda Şifa Hadisleri (İstanbul: Rağbet Yayınları, 2019); Vahîd b. Abdüsselam Bâli, es-Sârimu'l-bettâr fíttesaddî li's-seharat'il-eşrâr (Misır, 2008).

30 Kur'ân-ı Kerîm Meâli, çev. Halil Altuntaş - Muzaffer Şahin (Ankara: Diyanet İșleri Başkanlı̆̆ı Yayınları, 2009), el-Bakara 2/102; Tâhâ 20/69, 73.

31 Ebû Abdillâh Muhammed b. İsmâîl b. İbrâhîm Cu'fí Buhârî, Sahîhü'l-Buhârî (Beyrut: Dâru Tavkı'nNecât, 2001), "Hudûd", 6857; Müslim, el-Câmiu's-Sahîh, "Îmân", 145.

32 Ebû Zekeriyya Yahya b. Şerif b. Mürî Nevevî, Ravdatu't-Tâlibîn ve Umdetu'l-Muttakîn (Beyrut: elMektebetü'l-Îslâmî, 1991), 9/346; Takiyyuddin Ahmed b. Abdulhalim İbn Teymiyye, Mecmû'u'lfetâvâ (Riyad: Mecma' melik Fahd li tabâati'l-mushafi'ş-șerîf, 2005), 35/171.

33 Nevevî, Ravdatu't-Tâlibîn ve Umdetu'l-Muttakîn, 9/346.

34 Ebu'l-Hasan Ali b. Muhammed b. Habib Mâverdî, el-Hâvi'l-kebîr, thk. Ali Muhammed Muavvız (Beyrut: Dârüll-Kütübi'l-İlmiyye, 1999), 13/96; Ebû İshâk Cemâlüddîn İbrâhîm b. Alî b. Yûsuf Şîrâzî, el-Mühezzeb (Beyrut: Daru'l-Kütübi'l-İlmiyye, ts.), 3/261; İbnu'l-Hümâm, Fethu'l-kadîr, $6 / 99$.

35 İbn Hazm, Muhallâ bi'l-âsâr, 12/419-420. 
ğunu düşünsün yahut düşünmesin sadece büyü fiilini gerçekleștirdiği için kafir kabul edilir. Hanbelîler şöyle bir istisna ile büyücünün tekfir edilmesi konusunu yumuşatırlar: Büyücü büyüyü; ilaç duman, su veya cinler yardımı ile yapıyorsa bu durumda tekfir edilmez. ${ }^{36}$ Mâlikîler de bu görüşle aynı olduğu ifade edilse de onlar Şâfiîlerin görüşlerine benzer şekilde yapılan büyüde küfür içeren bir şeyin bulunmasını ve naslarda açıkça yasaklanan bir büyü türü (karı-koca arasını açma) ile meşgul olmayı şart koşmuşlardır. ${ }^{37}$

Büyü yapmayı öğrenmek ve öğretmek konusunda ifade edilen fikhî hükümler; büyücünün yaptığı fiilin küfür olup olmaması çerçevesindeki görüşlere paralel olarak gelişmiştir. Dolayısıyla Hanefî, Mâlikî ve Hanbelîlere göre hiçbir şekilde ve şartta büyünün öğrenime konu edilmesi câiz değildir. ${ }^{38} \mathrm{Bi}$ lakis yapılacak iş küfür olduğu için bu işe vesile olmakta aynı şekilde küfürdür. Bu görüște olan mezhepler içerisinde farklı görüşler olsa da genel hüküm bu yöndedir.

Şâfiîler her ne kadar büyünün öğrenime konu olmasını haram kabul etseler de yapılan işi küfür kapsamında değerlendirmezler. Ayrıca konuyla ilgili maslahat eksenli ve genel haram hükmünden farklı olarak şunları ifade ederler: Şayet bir fayda elde etmek, bir zararı def etmek veya büyünün hakikatine vakıf olarak tecrübe sahibi olmak için büyü öğrenilip öğretiliyorsa o zaman bu işin haram olduğu ifade edilemez. ${ }^{39}$

Büyü yapmanın haram olması hatta cumhura göre küfür olması nedeniyle bu fiilin öğrenime konu edilmesinin câiz olmadığı açıkça görülmektedir. Ayrıca yapılan istisnalar ve getirilen farklı açıklamalar, büyücülük konusunun ne kadar kötü bir eylem olduğunu ifade etmek bakımından yeterlidir.

\section{4. İSLAM CEZA HUKUKUNDA BÜYÜCÜLÜK}

Büyü ve büyücülügün mahiyeti ve bu eylemin fikhî hükümleriyle ilgili temel bilgilerin akabinde çalışmamızın temel problematiği olan büyücülüğün ceza hukuku yönü bu başlıkta ele alınacaktır.

Hanefîlere göre büyücünün cezası iki durumda ölümdür. a) şayet küfür

36 Muhammed Emin b. Ömer b. Abdülaziz ed-Dımaşkî İbn Âbidîn, Reddü'l-muhtâr ale'd-dürri'lmuhtâr șerhu tenviru'l ebsâr (Beyrut: Darü'l-Fikr, 1992), 4/240; İbnu'l-Hümâm, Fethu'l-kadîr, 6/99; İbn Kudâme, el-Muğnî, 9/29; Mansur b. Yûnus Buhûtî, Şerhu münteha'l-irâdât (Kahire: Alemü'l-Kütüb, 1993), 3/404; İbn Teymiyye, Mecmû'u'l-fetâvâ, 29/384; Muhammed b. Ali Şevkânî, Seylü'l-cerrâr el-mütedeffik 'alâ hadâ'iki'l-Ezhâr (Beyrut: Daru İbn Hazm, ts.), 676-869.

37 Ebü'l-Velîd Muhammed b. Ahmed İbn Rüșd el-Cedd, el-Beyân ve't-tahsîl ve'ş-șerh ve't-tevcîh ve'tta'lîl li mesâili'l-müstahrece (Beyrut: Dârü'l-Garbi'l-İslâmî, 1988), 16/443; Ebü'l-Abbâs Şihâbüddîn Ahmed b. İdrîs b. Abdirrahmân el-Mısrî Karâfî, ez-Zahîra (Beyrut: Dârü'l-Garbi'lİslâmî, 1994), 12/32.

38 İbnu'l-Hümâm, Fethu'l-kadîr, 6/99; İbn Rüşd el-Cedd, el-Beyân ve't-tahsîl, 16/443; İbn Kudâme, el-Muğnî, 9/29; Hanefîlerden İ bn Âbidin konuyla alakalı olarak Zahîratu'n-nâzır eserinin müellifi Ali b. Abdullah et-Tûrî'den şu görüşü nakleder: Harbîlerin büyü kanalıyla zararlarını def etmek için büyünün öğrenime konu edilmesi farzdır. Bk. İbn Âbidîn, Reddü'l-muhtâr, 1/44.

39 Mâverdî, el-Hâvi'l-kebîr, 13/97. 
gerektiren bir davranışla büyü yapıyorsa, b) büyücünün eyleminde küfür unsurları olmadığı halde, yaptığı fiil kapsamında ölüme yol açması sebebiyle öldürülür. Bu ceza kapsamında büyücünün Müslüman veya gayrimüslim olması durumu değiştirmeyecektir. Ayrıca büyücü cezasının tatbik dilmesi esnasında tövbeye davet edilmez ve tövbe etmesi durumda da infaz durdurulmaz. Tabiatıyla cezanın uygulanabilmesi için büyücünün yaptığı işi ikrar etmesi veya bir delille suçun ispat edilmesi gerekmektedir. ${ }^{40}$

Mâlikîlere göre de büyücü öldürülmelidir. Fakat bu hükmün icrası için büyücünün küfrüne dönük hüküm verilmesi gerekmektedir. Aksi takdirde büyü yapmanın bizatihi kendisi ölüm cezasının infazı için yeterli değildir. Suçun ispat edilmesinde en önemli argümanlardan birisi kişinin bu suçu işlediğini gizlememesi ve delillerin (beyyine) aşikâr olmasıdır. Büyücülük suçu neticesinde öldürülen kişi tövbe ederse malına el konulmaz, aksi takdirde küfür üzere öldüğü için malı da fey kapsamında hazineye aktarılır. Şayet büyücü yaptığı işi gizliyorsa bu durumda tövbeye davet edilmez ve tövbe etse de ceza düşmez. Mâlikîler bu hükümlerin Müslümanlara mahsus olduğunu ifade ederek zimmileri kapsam dışı bırakmışlardır. Zimmilerden büyücülük yapanların cezası ise ta'zirdir. Ancak yapılan büyü nedeniyle bir zarara sebebiyet verilmiş ise bu takdirde fâil zimmi de olsa öldürülür. Ayrıca Müslüman olması dışında pişmanlık duyması durumu değiştirmeyecektir. ${ }^{41}$

Şâfiî ve Zâhirîler büyücülük eylemini kayıtsız bir şekilde irtidâd olarak görmedikleri için büyücünün öldürülmesinin isabetli olmadığını ifade etmektedirler. Şayet küfür içeren bir büyüyle uğraşıyorsa işte bu durumda öldürülür. Ayrıca büyücü yaptığı büyü nedeniyle birisinin ölümüne sebebiyet verdiyse bu durumda da kısas uygulanarak ölüm cezasının tatbik edilebileceği görüşündedirler. Suçun ispatında ise büyücünün ikrarı delil olarak kabul edilir. Bu iki suç şeklinin kapsamı dışında kalan büyücülük suçunun cezası ta'zirdir. ${ }^{42}$

Hanbelîler ise büyücünün cezasının ölüm olduğunu ifade ederken; bü-

40 Osman b. Ali Zeylaî, Tebyînü'l-hakâik şerhu Kenzü'd-dekâik (Kahire: Matbaatü'l-Kübra'l-Emîriyye, 1313), 3/293; Zeynülâbidîn b. İbrahim İbn Nüceym b. Muhammed, el-Bahru'r-râik șerhu Kenzü'ddekâik (Kahire: Daru'l-Kitâbi'l-İslâmi, 2000), 5/139; İbnu'l-Hümâm, Fethu'l-kadîr, 6/98-99; İbn Âbidîn, Reddü'l-muhtâr, 1/43-45; 4/240-245.

41 İbn Rüșd el-Cedd, el-Beyân ve't-tahsîl, 16/443-444; Ebû Muhammed Abdülbâkîb. Yûsuf b. Ahmed el-Vefâî el-Mısrî Zürkânî, Şerhu muhtasarı Halîl (Beyrut: Dâru'l-'Ubeykân, 2002), 8/110-118; Ebû Abdillâh Muhammed b. Yûsuf b. Ebi'l-Kâsım el-Abderî el-Gırnâtî Mevvâk, et-Tâc ve'l-iklîl li muhtasari Halîl (Beyrut: Daru'l-Kütübi'l-İlmiyye, 1994), 8/371; Ebû Abdullah Muhammed b. Muhammed Abdurrahmân el-Mağribî Hattâb, Mevâhibü'l-celîl li șerh-i muhtasari'l-Halîl (Beyrut: Darü'l-Fikr, 1992), 6/279.

42 Ebû Abdullah Muhammed b. İdris b. Abbas Şâfiî, el-Ümm (Beyrut: Dârü'l-Marife, 1410), 1/293; Mâverdî, el-Hâvi'l-kebîr, 13/96-98; Nevevî, el-Mecmû'șerhu'l-Mühezzeb, 19/245-246; Ebü'l-Kasım Abdülkerîm b. Muhammed b. Abdilkerîm Kazvînî Rafii, Fethü'l-azîz fi Șerhi'l-Vecîz (Beyrut: Darü'lFikr, ts.), 10/126; Cüveynî, Nihâyetü'l-matlab fí dirâyeti'l-mezheb, thk. Abdülazîm Mahmûd ed-Dîb (Dârü'l-Minhâc, 2007), 17/120-122; İbn Hazm, Muhallâ bi'l-âsâr, 12/419-420. 
yücünün Müslüman ve yaptığı büyünün küfür içeriyor olmasının şart olduğunu beyan ederler. Zimmilerin ise zaten küfür üzere olduklarını, sadece bu suç nedeniyle ölüme mahkûm edilemeyecekleri görüşünü savunurlar. Tabiatıyla büyü nedeniyle birisinin ölümüne sebebiyet vermeleri durumunda k1sas uygulanarak öldürülürler. ${ }^{43}$

Fakîhlerin büyücülük suçunu işleyenlerin öldürülmesi yönünde vardıkları hükmün temel dayanağı ilgili nasslardır. Bu çerçevede Hz. Peygamber (s.a.): "Büyücünün (Sâhir) haddi kllıçla boynunu vurmaktır"44 buyurmuştur. Cessâs burada nassın mutlak olarak ifade edilmesini şöyle yorumlamaktadır: Büyücü vucûben öldürülür. Zira nass emir sîgasıyla gelmiștir. Ayrıca had cezası olarak ifade edildiği için fâilin tövbesi nedeniyle de ceza düşürülmez. ${ }^{45}$

Bir başka delil de Hz. Ömer'in (r.a.) bir mektubundaki şu ifadesidir: “ $E r$ kek ve kadın tüm büyücüleri öldürünüz". ${ }^{46}$ Buna göre de büyücüler mürted oldukları için öldürülür. İbn Kudâme bu sözün üzerine sahabe arasında herhangi bir ihtilâf olmaması nedeniyle sükûtî icmânın varlığını ifade eder. ${ }^{47}$

Şâfiî ve Zâhirîlerin delilleri ise Hz. Peygamber'in (s.a.) şu sözleridir: “Kendisinden başka ilâh olmayan Allah'a yemin ederim ki, Allah'tan başka ilâh olmadiğına ve benîm Allah'ın elçisi olduğuma şehâdet eden Müslüman bir kişinin kanı helâl değildir. Ancak üç kişi müstesna; İslâm'ı terk eden, cemaati bırakan yahut cemaatten ayrlan, zina eden dul ve cana karşs can". ${ }^{48} \mathrm{Bu}$ ifadelerin kapsamına büyücü girmediği için Şâfiî ve Zâhirîler büyücünün öldürülmeyeceğini beyan etmektedirler.

Bütün bu görüşlerden hareketle bir değerlendirme yapılacak olursa kanaatimizce büyücünün küfrünün tespit edilmesi halinde öldürülmesi daha isabetlidir. Bu şekilde öldürme ise hudûd kapsamında değerlendirilmelidir. Ayrıca küfrü tespit edilememiş fakat büyücülüğü konusunda tereddüt bulunmayan suçlu ta'zir kapsamında oldukça caydırıcı olmak kaydıyla cezalandırilmalıdır. Hatta İmam Ahmed'den de (ö. 241/855) ta'zir kapsamında büyücünün öldürülebileceği yönünde bir nakil vardır. ${ }^{49}$ Zira büyünün metafizik

43 İbn Kudâme, el-Muğnî, 9/29-33; Ebû İshâk Burhânüddîn İbrâhîm b. Muhammed b. Abdillâh erRâmînî ed-Dımașkî İbn Müflih, el-Mübdi' fí șerhi'l-Mukni' (Beyrut, 1997), 7/487; Alâuddîn Ebü’lHasan Ali b. Süleyman Merdâvî, el-İnsâf fî̀ marifeti'r-râcih ani'l-hilâf alâ mezhebi'l-İmam Ahmed (Beyrut: Dâru İhyâi't-Türâsi'l-Arabî, ts.), 10/351-353; Buhûtî, Keșşâfü'l-kınâ' an metni'l-İknâ', 6/187.

44 Tirmizî, el-Câmiu'l-kebîr, “Hudûd” 1460; Ebû Abdullah İbnü'l-Beyyi’ Muhammed Hâkim Nîsâbûrî, el-Müstedrek ale's-sahîhayn, thk. Mustafa Abdülkâdir Atâ (Beyrut: Dârü'l-Kütübi'l-İlmiyye, 1411), "Hudûd" 8073.

45 Cessâs, Ahkâmü'l-Kur'ân, 1/65.

46 Ebû Bekr Ahmed b. el-Hüseyin b. Ali Beyhakî, es-Sünenü'l-kübrâ (Beyrut: Daru'l-Kütübi'l-İlmiyye, 2003), "Kasâme” 16498; Cessâs, Ahkâmü'l-Kur'ân, 1/60.

47 İbn Kudâme, el-Muğnî, 9/31.

48 Buhârî, Sahîhü'l-Buhârî, “Diyât” 6878; Müslim, el-Câmiu's-Sahîh, "Kasâme” 1676.

49 Mustafa b. Sa'd b. Abduh es-Suyûtî Ruhaybânî, Metâlibu uli'n-nuhâ fî şerhi Ğâyeti'l-muntehâ (Dımaşk: el-Mektebetü'l-Îslâmî, 1994), 6/304. Metin şu şekildedir: 
bir olgu olması nedeniyle suçun fâilinin önlenmesi yani büyü yapmadan alıkonulması son derece zordur. Dolayısıyla Müslümanların büyü ve etkilerinden korunması maslahat gereğidir. Büyü yapmak üzere büyücüye başvuran kişilerin durumu ise konunun bir diğer boyutudur.

Klasik fikıh literatüründe büyü suçunun cezasından başka, büyücünün yaptığı büyü ameliyesine karşılık ücret alması da değerlendirilmiştir. Bu kapsamda büyücü ve danışan (büyü yaptırmak isteyen) arasında gerçekleștirilen akit (icâre/ecîr-i müşterek) batıldır. Hanefî ve Mâlikîlere göre danışanın büyü yaptırmak istemesi durumunda, bilfiil büyü eylemini gerçekleștirmediği için öldürülmez, ta'zir edilir. ${ }^{50}$ Şâfiî ve Hanbelîler de aynı görüştedirler. ${ }^{51}$

Mevcut bir büyünün bozulması/çözülmesi ('ilâc) için yapılan hizmet sözleşmesi Hanefî, Mâlikî Şâfiî ve Hanbelîlere göre câizdir. ${ }^{52}$

Büyücülük fiilinin günümüz pozitif hukukunda ismen tanımlanmamış olması, büyücülere verilecek cezai müeyyidelerin tespiti konusunda klasik fikıh literatüründe zikredilmiş olan cezalardan istifade etmeyi imkânsız kılmıştır. Diğer taraftan, Pozitif hukukta ismen (büyü ve büyücülük vb. isimlerle) suç kapsamında zikredilmediği ve cezai müeyyide tanımlanmadığı için modern dönem İslam hukukçuları da bu suça verilecek ceza konusunda bir güncellemeye gitmemiş ve yeni ictihadlarda bulunmamışlardır.

\section{DEĞERLENDİRME VE ÖNERILER}

Büyücülük kavram olarak genel bir anlam yapısına sahip olsa da illüzyon dışındaki tüm durumların konumuzu ilgilendirdiği hususu dikkate alınmalıdır. Gaybden (geçmiş ve gelecek) haber verme, büyü için cinler ve şeytanlardan yardım alma ve mevcut büyüyü büyü ile çözme, karı koca arasını bulma veya bozma vb. tüm olağandışı durumların tamamı konumuz kapsa-

50 İbn Âbidîn, Reddü'l-muhtâr, 6/93; Hattâb, Mevâhibü'l-celîl li șerh-i muhtasari'l-Halîl, 6/280.

51 Celâlüddîn Muhammed b. Ahmed Mahallî, Şerhu'l-Mahallî ale'l-Minhâc, (Amîra ve Kalyûbî hâşiyeleriyle birlikte) (Beyrut: Darü'l-Fikr, 1995), 3/71; Ruhaybânî, Metâlibu uli'n-nuhâ, 3/604.

52 İbn Âbidîn, Reddü'l-muhtâr, 6/93; Hattâb, Mevâhibü'l-celîl li şerh-i muhtasari'l-Halîl, 6/280; Mahallî, SSerhu'l-Mahallî ale'l-Minhâc, 3/71; Ruhaybânî, Metâlibu uli'n-nuhâ, 3/604; Mevcut bir büyünün bozulmasıyla ilgili olarak fetâvâ literatürünün önemli örneklerinden biri olan Neticetü'lfetâvâ adlı eserde nakledilen bir soruyu ve bu soruya verilen cevabı bu aşamada aktarmayı isabetli buluyoruz. Ebussuûd aleyhi rahmetü'l-Vedûd hazretlerinden, 'Bir kasaba makberesinde defn olunan mevtâdan Zeyd-i müteveffâ cazı olmağla, gecelerde bazı kimesnelerin menzillerine varub ya fülân, ya fülân deyu nidâ etmekle ol kimesneler fevt olup, daima bu vech üzere telef-i nüfûsi nâsa sebeb olduğu meşhûr ve mütevâtir olub, âmmeye zararı olsa bunun defi'ne çare nedir?' deyu istiftâ olundukta cevablarında 'Zeyd-i mezbûr kabrinden ihrac ve ra'si kat' olunur' deyu iftâ buyurmuşlar. Cevab-ı mezbûr bir asla mübtenî olub ber vech üzere amel olunmakta beis var mıdır? el-Cevab: Bu hususta mu'teberât-ı kütüb-i fikhiyyede bir mesele görülmemiștir. Lakin cevâb-ı mezbûr kütüb-i usûlde mastûr olan

يُتحمل الضرر الخاص لدفع الضرر العام، واذا تعارض مفسدتان روعى اعظمهما ضروا بارتكاب الخفهما asılları üzerine mübtenîdir. Cevâb-ı mezkûr ile elân amel olunmakta beis yoktur. Konuyla ilgili bu kaynağa delalet eden Prof. Dr. Ahmet Yaman hocama teșekkür ederim. Seyyid Ahmed Efendi Seyyid Hâfız Mehmed b. Ahmed el-Gedûsî, Netîcetü'l-fetâvâ Şeyhülislam fetvaları, thk. Süleyman Kaya vd. (İstanbul: Klasik, 2014), 389-390. 
mında düşünülmelidir. Cinlerin ve şeytanların insana musallat olması ise konumuz kapsamında değerlendirilmemiştir.

Büyünün gerek mahiyeti/hakikati gerek sonuçları bakımından metafizik bir yapıya sahip olması nedeniyle net bir kanaate ulaşmak oldukça zordur. Bu bakımdan ceza hukuku bağlamında bir bireyin cezalandırılması söz konusu olunca problem daha da büyümektedir. Ayrıca Hanefîler ile Mu'tezile'nin büyünün hakikatinin olmadığını açıkça belirtmelerine rağmen yine de büyücünün cezalandırılması gerektiğini ifade etmeleri oldukça dikkat çekicidir.

Günümüzde büyü ve büyücülük toplumun bazı kesimleri tarafından önem verilen gerek müspet gerekse menfi yönleriyle başvurulan olgulardan biridir. Bu kapsamda bireyler etkilenmekte ve istismar edilmektedir. Ne yazık ki pozitif hukukun konuyla ilgili ceza algisı; halkın dini duygularının istismarı, bu duygular üzerinden haksız kazanç elde etme ve nitelikli dolandırıcılık dışında değildir. Büyücülük suçunun bu kapsamda cezalandırılmasının "caydırıcılığı"! bir yana büyücülük yapan şahsın sebep olduğu zararın cezasız kalması da cabasıdır. ${ }^{53} \mathrm{Ne}$ yazık ki işin ceza boyutundan ziyade medyumluk adı altında açılan serbest ticarethane statüsünde ve vergi mükellefiyetliğini belgeleyen işletmeler kanalıyla "legal" bir yapı algısı olușturulmaktadır. ${ }^{54}$ Halbuki İslam ceza hukukunun konuya yaklaşımındaki ciddiyet hem caydırıcllık hem de mağdurların hakları bağlamında oldukça adaletlidir.

İslam hukuku işin başında yani büyücülük suçu ve sebep olduğu olumsuzluklar ortaya çıkmadan önce büyünün meşru bir eylem olmadığını ifade ederek bu eylem sebebiyle uhrevi cezalarla bireyleri bu işten sakındırmaktadır. Bu kapsamda küfrü gerektiren büyü kapsamında verilen ölüm cezasının oldukça caydırıcı olacağı takdir edilmelidir.

Pozitif ceza hukukçularının konuyla alakalı teori düzeyinde birtakım öneriler hazırlaması ve bu önerilerin İslam ceza hukukunun verilerinden istifade edilerek ortaya konulması bu çalışmanın başlıca önerileri arasındadır. Zira büyüye karşı savunmasız kalan masum bireylerin büyücüye uygulanacak caydırıcı yaptırımlar sayesinde korunacağı bir hakikattir.

Suçun tespit edilmesi ise yargı erkinden ziyade yürütmenin (içişleri bakanlığına bağlı kolluk kuvvetleri; jandarma ve polis) faaliyetidir. Bu kapsamda maddi suçlarla alakalı kriminologlardan faydalanıldığı gibi büyü suçunun tespiti için de konunun uzmanlarından faydalanılmalıdır. Tabiatıyla bu durumda ilgili uzmanlığın oluşturulabilmesi için büyünün öğrenime konu edilmesi gerekmektedir. Kanaatimizce modern dönemde metafizik olgulara pozitivist yaklaşımlar, bu duruma karşı çıkacaktır. Halbuki büyü soyut bir

53 Pozitif ceza hukukunda suçlu için öngörülen ceza iki yıldan yedi ylla kadar hapis ve beș bin güne kadar adlî para cezasıdır. Türk Ceza Kanunu, 157/1.

54 “Medyumun Vergi Vermesi Medyumluğu Yasal Hale Getirir mi?” (Erişim 22 Nisan 2020). 
olgu iken neden olduğu sonuç son derece somuttur. Bu nedenle hem suçun tespiti hem de mevcut vaka incelemeleri için uzman görüşüne başvurulması gerekmektedir. Bu kapsamda İslam hukukuna göre sadece vaka tespiti için Şâfiîlerin de ifade ettiği üzere büyünün öğrenime konu edilmesinin câiz olacağı kanaatindeyiz.

Cumhur fukahanın küfrü gerektiren bir büyü nedeniyle büyücünün öldürülmesi yönündeki kanaatinin isabetli olduğunu düşündüğümüz halde, suçun ispatıyla alakalı geliştirilen algoritmaların yeniden düşünülmesi gerektiği bir gerçektir. Nitekim klasik fikıh literatüründe ifade edilen ispat vasıtalarıyla suç kendiliğinden tespit edilebilir veya mevcut suçlar gizli kalabilir. Fakat şüpheli vakalarda, vaka tespiti neticesinde bir hüküm verecek olan yargıcın (kâdî) objektif karar verebilmesi için uzman bir ekipten yararlanması oldukça önemlidir. Bu kapsamda yürütme erki olan siyasi otoritenin; objektif, suiistimallerden uzak ve denetlenebilir bir yapı/kurum oluşturması gerekmektedir. Tabi ki bu yapının oluşturulması aşamasında uzman psikologlar, teologlar, hukukçular ve konuyla ilgisinin olduğu düşünülen diğer alanların uzmanlarından yardım alınması gerekmektedir. Zira bu eylemin ve suçun metafizik bir yapıda olması nedeniyle suçun tespitindeki her türlü sübjektif yargıların önüne geçilmesi adaletli bir yargı aşaması için zaruridir.

$\mathrm{Bu}$ araştırmada büyücülük suçunun İslam ceza hukuku bağlamında ele alınması nedeniyle bazı hususların araștırılması gerektiği sonucuna varılmıştır. Bunlar; pozitif hukukta büyücülük suçu ve cezası, büyünün mahiyeti çerçevesinde felsefi arka planı, toplumun büyü algısı ve etkileri bağlamında sosyolojik boyutu, büyücüyü büyü yapmaya iten ruhsal durum ve kendisine büyü yapıldığını düşünen bireylerin yaşadıkları bağlamında psikolojik arka plan, geçmişte ve günümüzde dinlerin büyü konusundaki geliştirdikleri algoritmalardır. Tabiatıyla ifade ettiğimiz bu hususların araştırılması neticesinde İslam ceza hukukunda verilen hükümlerde bir değişiklik olmayacaktır. Ama suçun tespiti ve önlenmesine dönük tedbirler için bu konuların mutlaka ele alınması gerekmektedir.

Son olarak araștırmacılara önerimiz, kişi/şahıs hukuku kapsamında büyünün ehliyete etkileriyle ilgili çalışma yapmalarıdır. Bu çerçevede şu başlıklara değinilmelidir: Büyü yapılan kimsenin ibadet sorumluluğu, muamelatla ilgili gerçekleştirdiği tasarruflar; velâyet, vasiyet, ortaklık kurma ve vekâlet vd. işlemler, ayrıca nikâh akdi ve sonuçlarıyla ilgili konular (talâk, nafaka vb.), son olarak suçlar ve cezai ehliyet.

\section{KAYNAKÇA}

Ahmed b. Hanbel. Müsned. thk. Şuayb el-Arnaût, Âdil Mürşid vd. Müessesetü'r-Risâle, 1421.

Kur'ân-ı Kerîm Meâli. çev. Halil Altuntaş - Muzaffer Şahin. Ankara: Diyanet İșleri

Başkanlığı Yayınları, 3. Basım, 2009.

Atmaca, Veli. Hadislerde Rukye Hz. Peygamber ve Sahabenin Uygulamaları Ișığında 
Sifa Hadisleri. İstanbul: Rağbet Yayınları, 2019.

Aynî, Ebû Muhammed Bedreddin Mahmûd b. Ahmed b. Musa Hanefi. Umdetü'l-kârî şerhu sahîhi'l-Buhârî. Beyrut: Dâru İhyâi't-Türâsi'l-Arabî, ts.

Bâli, Vahîd b. Abdüsselam. es-Sârimu'l-bettâr fî't-tesaddî li's-seharat'il-eşrâr. Mısır, 21. Basım, 2008.

Begavî, Ebû Muhammed Muhyissünne el-Hüseyn b. Mes'ûd b. Muhammed el-Ferrâ'. Me âlimü't-tenzîl. 8 Cilt. Riyad: Dâru's-Selâm, 1997.

Begavî, Ebû Muhammed Muhyissünne el-Hüseyn b. Mes'ûd b. Muhammed el-Ferrâ'. Şerhu's-sünne. 15 Cilt. Beyrut: Mektebetü'l-Îslâmî, 1983.

Beyhakî, Ebû Bekr Ahmed b. el-Hüseyin b. Ali. es-Sünenü'l-kübrâ. Beyrut: Daru'lKütübi'l-İlmiyye, 2003.

Beyzâvî, Ebû Saîd Nasîruddîn Abdullah b. Ömer b. Muhammed. Envâru't-tenzîl ve esrâru't-te'vîl. 5 Cilt. Beyrut, 1998.

Buhârî, Ebû Abdillâh Muhammed b. İsmâîl b. İbrâhîm Cu'fî. Sahîhü'l-Buhârî. 9 Cilt. Beyrut: Dâru Tavkı'n-Necât, 2001.

Buhûtî, Mansur b. Yûnus. Keşşâfü'l-kınâ'an metni'l-İknâ'. 6 Cilt. Riyad: Daru'l-Kütübi'lİlmiyye, 2003.

Buhûtî, Mansur b. Yûnus. Şerhu münteha'l-irâdât. 3 Cilt. Kahire: Alemü'l-Kütüb, 1993.

Bukeyrî, Ahmed Fethî Muhammed Abdüllatif. Ahkâmu'l-müte'allika bi's-sihr ve'ssehara fi'l-fikhi'l-İslâmî. Kuala Lumpur: Câmiatu'l-Medîne el-Âlemiyye, 2016.

Cemel, Süleyman b. Ömer b. Mansûr el-Ezherî. Fethu'l-Vehhâb bi tavzîh-i şerhi menheci't-tullâb. Kahire: Darü'l-Fikr, 1994.

Cessâs, Ebû Bekr Ahmed b. Alî Râzî. Ahkâmü'l-Kur'ân. 3 Cilt. Beyrut, 1994.

Cüveynî. Nihâyetü'l-matlab fî dirâyeti'l-mezheb. thk. Abdülazîm Mahmûd ed-Dîb. 20 Cilt. Dârü'l-Minhâc, 2007.

Çelebi, İlyas. "Sihir". Türkiye Diyanet Vakfı İslâm Ansiklopedisi. Erişim 17 Nisan 2020. https://islamansiklopedisi.org.tr/sihir

Çelebi, İlyas. "Vefk". Türkiye Diyanet Vakfı İslam Ansiklopedisi. Erișim 19 Nisan 2020. https://islamansiklopedisi.org.tr/vefk

Ebû Dâvûd, Süleyman b. Eş'as b. İshak el-Ezdi. Sünenü Ebî Dâvûd. thk. Şuayb elArnaût, Muhammed Kâmil. 7 Cilt. Dârü'r-Risâleti'l-Âlemiyye, 2009.

Hâkim Nîsâbûrî, Ebû Abdullah İbnü'l-Beyyi' Muhammed. el-Müstedrek ale's-sahîhayn. thk. Mustafa Abdülkâdir Atâ. 4 Cilt. Beyrut: Dârü'l-Kütübi'l-İlmiyye, 1411.

Hattâb, Ebû Abdullah Muhammed b. Muhammed Abdurrahmân el-Mağribî. Mevâhibü'l-celîl li şerh-i muhtasari'l-Halîl. 6 Cilt. Beyrut: Darü'l-Fikr, 1992.

İbn Âbidîn, Muhammed Emin b. Ömer b. Abdülaziz ed-Dımaşkî. Reddü'l-muhtâr ale'dDürri'l- muhtâr şerhu Tenviru'l ebsâr. Beyrut: Darü'l-Fikr, 1992.

İbn Hacer, Ebü'l-Fazl Şihâbüddîn Ahmed b. Alî b. Muhammed. Fethü'l-bârî şerhu sahîhi'l-Buhârî. Beyrut, 1960.

İbn Hazm, Ebû Muhammed b. Ali b. Ahmed b. Saîd ez-Zahiri. Muhallâ bi'l-âsâr. 12 Cilt. Beyrut: Darü'l-Fikr, 1934.

İbn Kudâme, Ebû Muhammed Muvaffakuddîn Abdullah b. Ahmed b. Muhammed b. Kudâme Cemmâîlî Makdisî. el-Muğnî. 10 Cilt. Mektebetü'l-Kâhire, 1968.

İbn Manzûr, Muhammed b. Mükerrem. Lisânu'l-'Arab. 15 Cilt. Beyrut: Daru Sadr, 1993.

İbn Müflih, Ebû İshâk Burhânüddîn İbrâhîm b. Muhammed b. Abdillâh er-Râmînî edDımașkî. el-Mübdi'fî şerhi'l-Mukni'. 8 Cilt. Beyrut, 1997.

İbn Nüceym, Zeynülâbidîn b. İbrahim, b. Muhammed. el-Bahru'r-râik şerhu Kenzü'ddekâik. 8 Cilt. Kahire: Daru'l-Kitâbi'l-İslâmi, 2. Basım, 2000.

İbn Rüşd el-Cedd, Ebü'l-Velîd Muhammed b. Ahmed. el-Beyân ve't-tahsîl ve'ş-şerh ve't- 
tevcîh ve't-ta'lîl li mesâili'l-müstahrece. 20 Cilt. Beyrut: Dârü'l-Garbi'l-İslâmî, 1988.

İbn Teymiyye, Takiyyuddin Ahmed b. Abdulhalim. Mecmû'u'l-fetâvâ. Riyad: Mecma' melik Fahd li tabâati'l-mushafi'ş-şerîf, 2005.

İbnu'l-Hümâm, Kemalüddin Muhammed b. Abdulvâhid. Şerhu Fethu'l-Kadîr. 10 Cilt. Beyrut: Darü'l-Fikr, 2003.

Kâdî Abdülcebbâr, Ebü'l-Hasen Kâdı'l-kudât Abdülcebbâr b. Ahmed b. Abdilcebbâr el-Hemedânî. Tenzîhü'l-Kur'ân 'ani'l-metâ'in. Kahire, ts.

Kal'acî, Muhammed Revvâs - Kuneybî, Hâmid Sâdık. Mu'cemu luğati'l-fukahâ. Beyrut: Dâru'n-Nefâis, 1985.

Karâfî, Ebü'l-Abbâs Şihâbüddîn Ahmed b. İdrîs b. Abdirrahmân el-Mısrî. Envârü'lburûk fì envâ'i'l-fürûk. 6 Cilt. Beyrut, 2014.

Karâfî, Ebü'l-Abbâs Șihâbüddîn Ahmed b. İdrîs b. Abdirrahmân el-Misrî. ez-Zahîra. 14 Cilt. Beyrut: Dârü'l-Garbi'l-İslâmî, 1994.

Kaya, Aydın. Kur'an'da Mâhiyet Açısından Sihir-Mucize Karşılaştırması. Sivas: Cumhuriyet Üniversitesi, Yüksek Lisans Tezi, 2015.

Mahallî, Celâlüddîn Muhammed b. Ahmed. Şerhu'l-Mahallî ale'l-Minhâc, (Amîra ve Kalyûbî hâşiyeleriyle birlikte). 4 Cilt. Beyrut: Darü'l-Fikr, 1995.

Mâtürîdî, Ebû Mansûr Muhammed b. Muhammed b. Mahmûd el-Mâtürîdî esSemerkandî. Kitâbu't-Tevhîd. Mısır, ts.

Mâverdî, Ebu'l-Hasan Ali b. Muhammed b. Habib. el-Hâvi'l-kebîr. thk. Ali Muhammed Muavvız. 19 Cilt. Beyrut: Dârü'l-Kütübi'l-İlmiyye, 1999.

Merdâvî, Alâuddîn Ebü'l-Hasan Ali b. Süleyman. el-İnsâf fî marifeti'r-râcih ani'l-hilâf alâ mezhebi'l-İmam Ahmed. 12 Cilt. Beyrut: Dâru İhyâi't-Türâsi'l-Arabî, 2. Basım, ts.

Mevvâk, Ebû Abdillâh Muhammed b. Yûsuf b. Ebi'l-Kâsım el-Abderî el-Gırnâtî. et-Tâc ve'l-iklîl li-muhtasari Halîl. 8 Cilt. Beyrut: Daru'l-Kütübi'l-İlmiyye, 1994.

Müslim, b. Haccac Ebu'l-Hüseyn el-Kuşeyrî. el-Câmiu's-Sahîh. I-V Cilt. Beyrut: Dâru ihyâi't-türâsi'l-arâbî, ts.

Nevevî, Ebû Zekeriyya Yahya b. Şerif b. Mürî. el-Mecmû' șerhu'l-Mühezzeb (Fethu'l'azîz ve Telhîsu'l-habîr ile Sübkî'nin ve Mutîîi'nin tekmileleri ile birlikte). Beyrut: Darü'l-Fikr, ts.

Nevevî, Ebû Zekeriyya Yahya b. Şerif b. Mürî. Ravdatu't-Tâlibîn ve Umdetu'l-Muttakîn. 12 Cilt. Beyrut: el-Mektebetü'l-Îslâmî, 1991.

Rafii, Ebü'l-Kasım Abdülkerîm b. Muhammed b. Abdilkerîm Kazvînî. Fethü'l-azîz fî şerhi'l-vecîz. 12 Cilt. Beyrut: Darü'l-Fikr, ts.

Ruhaybânî, Mustafa b. Sa'd b. Abduh es-Suyûtî. Metâlibu uli'n-nuhâ fî şerhi Ğâyeti'lmuntehâ. 6 Cilt. Dımașk: el-Mektebetü'l-Îslâmî, 1994.

Sa'dî Ebû Habîb. Kâmûsu'l-fikhî luğaten ve ıstılâhen. Dımaşk: Darü'l-Fikr, 2. Basım, 1988.

Sa'îdî, Huseyn Cüley'ab. es-Sihr hakîkatuhû ve hukmuhû, ts.

Seyyid Ahmed Efendi - Seyyid Hâfız Mehmed b. Ahmed el-Gedûsî. Netîcetü'l-fetâvâ Şeyhülislam Fetvaları. thk. Süleyman Kaya vd. İstanbul: Klasik, 2014.

Şâfiî, Ebû Abdullah Muhammed b. İdris b. Abbas. el-Ümm. 8 Cilt. Beyrut: Dârü'lMarife, 1410.

Şevkânî, Muhammed b. Ali. Seylü'l-cerrâr el-mütedeffik 'alâ hadâ'iki'l-Ezhâr. 1 Cilt. Beyrut: Daru İbn Hazm, ts.

Şîrâzî, Ebû İshâk Cemâlüddîn İbrâhîm b. Alî b. Yûsuf. el-Mühezzeb. 3 Cilt. Beyrut: Daru'l-Kütübi'l-İlmiyye, ts.

Tanyu, Hikmet. "Büyü”. Türkiye Diyanet Vakfi İslâm Ansiklopedisi. Erişim 17 Nisan 
2020. https://islamansiklopedisi.org.tr/buyu

Tehânevî, Muhammed b. A'la b. Ali el-Fârukî el-Hanefî. Keşşâf ıstılâhâti'l-funûn. 2 Cilt. Beyrut: Mektebetu Lübnân, 1996.

Tirmizî, Ebû İsa Muhammed b. İsa b. Sevre Sülemi. el-Câmiu'l-kebîr. thk. Beşşâr Avvâd Marûf. 6 Cilt. Beyrut: Dârü'l-Garbi'l-İslâmî, 1998.

Uludă̆, Süleyman. "Azâim". Türkiye Diyanet Vakfi İslam Ansiklopedisi. Erişim 19 Nisan 2020. https://islamansiklopedisi.org.tr/azaim

Zebîdî, Ebü'l-Feyz Muhammed el-Murtazâ b. Muhammed b. Muhammed b. Abdirrezzâk el-Bilgrâmî el-Hüseynî. Tâcu'l-'arûs min cevâhiri'l-kâmûs. 40 Cilt. Riyad: Daru'l-Hidâye, ts.

Zekeriyyâ el-Ensârî, Ebû Yahya Zeynüddîn Zekeriya b. Muhammed b. Ahmed esSüneykî. Esne'l-metâlib fí şerhi Ravzi't-tâlib. 4 Cilt. Beyrut: Daru'l-Kütübi'lİlmiyye, 2000.

Zeylaî, Osman b. Ali. Tebyînü'l-hakâik şerhu Kenzü'd-dekâik. 6 Cilt. Kahire: Matbaatü'lKübra'l-Emîriyye, 1313.

Zürkânî, Ebû Muhammed Abdülbâkî b. Yûsuf b. Ahmed el-Vefâî el-Misrî. Şerhu muhtasarı Halîl. 8 Cilt. Beyrut: Dâru'l-'Ubeykân, 2002.

"https://sozluk.gov.tr/", ts. Erișim 31 Mart 2020

"İllüzyon Nedir? Neden Algı Yanılması Yaşarız". Erişim 19 Nisan 2020. https://www.fikir.gen.tr/illuzyon-nedir-neden-algi-yanilmasi-yasariz/

"Medyumun Vergi Vermesi Medyumluğu Yasal Hale Getirir mi?” Erișim 22 Nisan 2020. http://www.gchukukburosu.com/?p=621

"Rukye". Mv. F. 23/96-98. Kuveyt, ts.

"Sihr". Mv. F. 24/259-269. Kuveyt, ts.

TCK, Türk Ceza Kanunu. Nitelikli Dolandırıcılı 5237-158/1-a) bendi (26 Eylül 2004). Erişim 19 Nisan 2020.

https://www.mevzuat.gov.tr/MevzuatMetin/1.5.5237.pdf 